\title{
PENGARUH DEWAN PENGAWAS SYARIAH DAN INTELLECTUAL CAPITAL TERHADAP PENGUNGKAPAN CORPORATE SOCIAL RESPONSIBILITY DENGAN KINERJA KEUANGAN SEBAGAI VARIABEL MEDIASI (STUDI EMPIRIS PERBANKAN SYARIAH DI INDONESIA)
}

\author{
Febty Nurhikmah', Winarsih ${ }^{\mathbf{2}}$, Metta Kusumaningtyas ${ }^{\mathbf{3}}$ \\ 1,3STIE BANK BPD Jateng, Semarang \\ 2 Universitas Sultan Agung, Semarang \\ $\triangle$ febtynurhikmah94@gmail.com
}

\begin{abstract}
Corporate Social Responsibility Disclosure (CSR) is the information contained in the annual report that reveals information beyond the mandatory disclosure. Measurement of CSR disclosure in the Islamic perspective using ISR index (Islamic Social Reporting) which included the accounts of reporting CSR activities according to Islamic principles. This study aims to examine the relationship of the Sharia Supervisory Board and Intellectual Capital on Corporate Social Responsibility Disclosure with financial performance as a mediating variable. The study was conducted on annual report Islamic banking in Indonesia since the year 2010-2017. The study sample of 11 Islamic banks were selected through purposive sampling technique. Data analysis techniques used in this study is SEM-PLS using software smartpls 3.0. The result showed that Sharia Supervisory Board and Intellectual Capital have related negative and not significant to Corporate Social Responsibility Disclosure. However, based on the role of financial performance variables as variables mediating the relationship between Sharia Supervisory Board with Corporate Social Responsibility Disclosure show negative and not significantly, while the relationship between Intellectual Capital with Corporate Social Responsibility Disclosure showed positive and significant.
\end{abstract}

Keywords : Corporate Social Responsibility, Sharia Supervisory Board, Intellectual Capital

\section{LATAR BELAKANG}

Pengungkapan (disclosure) mengandung arti bahwa laporan keuangan harus memberikan informasi dan penjelasan yang cukup mengenai hasil aktivitas suatu unit usaha (Ghozali dan Chariri, 2007). Informasi yang dimuat dalam laporan tahunan ada dua jenis yaitu pengungkapan wajib dan pengungkapan sukarela. Laporan tahunan dengan pengungkapan wajib (mandatory disclosure) yaitu pengungkapan informasi yang wajib diberitahukan sebagai mana diatur dalam Bapepam. Laporan tahunan dengan pengungkapan sukarela (voluntary disclosure) yaitu pengungkapan informasi diluar pengungkapan wajib yang diberikan dengan sukarela oleh perusahaan kepada para pemakai yang kemudian lebih dikenal dengan Corporate Social Responsibility (yang selanjutnya disingkat CSR) atau Tanggung Jawab Sosial Perusahaan (Yularto dan Chariri, 2003 dalam Fauzan, 2010). 
Entitas bisnis yang berkembang pesat di Indonesia salah satunya adalah perbankan syariah. Perkembangan bank syariah ini dipengaruhi oleh beberapa sumber daya perusahaan yang menunjang penciptaan nilai dan keuntungannya. Sumber daya perusahaan dibedakan menjadi dua jenis yaitu sumber daya berwujud (tangible resources) dan sumber daya tidak berwujud (intangible resources). Sumber daya berwujud merupakan aset berwujud dan tak berwujud yang dapat disajikan dalam laporan posisi keuangan (neraca). Sumber daya tak berwujud adalah aset tak berwujud yang tidak dapat disajikan dalam laporan posisi keuangan. Sumber daya berwujud dapat digambarkan dengan adanya tanggung jawab keuangan yang ditunjukkan dengan ukuran moneter, akuntansi maupun rasio- rasio tertentu harus dilengkapi dengan kinerja non-keuangan seperti pelaksanaan dan pengungkapan CSR serta penerapan good corporate governance.

Pengungkapan CSR bagi entitas bisnis merupakan bagian dari kewajiban perusahaan setelah munculnya UU No. 40 tahun 2007 tentang Perseroan Terbatas Bab IV pasal 66 ayat 2b dan Bab V pasal 74 yang disahkan pada 20 Juli 2007. Kedua pasal tersebut menjelaskan bahwa laporan tahunan perusahaan harus mencerminkan tanggung jawab sosial, bahkan perusahaan yang kegiatan usahanya di bidang dan/atau berkaitan sumber daya alam harus melaksanakan tanggung jawab sosial. Entitas bisnis berbasis syariah seperti perbankan syariah juga memiliki pijakan dalam melaksanakan dan mengungkapkan aktivitas CSR, seperti yang diatur dalam Undang-Undang No. 21 Tahun 2008 tentang Perbankan Syariah. Peraturan tersebut menyebutkan bahwa Bank Syariah dan Unit Usaha Syariah (UUS) dapat menjalankan fungsi sosial dalam bentuk penerimaan zakat, infak, sedekah atau dana sosial lain dan menyalurkannya kepada organisasi pengelola zakat. Selain itu juga bisa menghimpun dana wakaf (uang) dan menyalurkannya kepada pengelola wakaf (nazhir) sesuai kehendak pemberi wakaf (wakif). Perbankan syariah dalam melaksanakan kegiatan operasionalnya akan membentuk baitul maal untuk mengelola CSR dan zakat, sedekah, dan qard hassan (pinjaman tanpa profit).

Pelaksanaan kegiatan CSR yang sesuai dengan perspektif Islam membutuhkan alat ukur guna mengukur seberapa besar perbankan syariah mengungkapan tanggung jawab sosialnya. Pengukuran tersebut adalah indeks Global Reporting Initiative (GRI), indeks ini belum banyak mengungkapkan prinsip syariah di dalamnya, dan indeks Islamic Social Reporting (ISR) yang berlandaskan pada prinsip syariah dalam pengungkapan CSR entitas bisnis tersebut. Haniffa (2002) dalam Fitria dan Hartanti (2010) membuat lima tema pengungkapan Indeks ISR, yaitu tema pendanaan dan investasi, tema produk dan jasa, tema karyawa, tema masyarakat, dan tema lingkungan hidup. Lima tema pengungkapan tersebut dikembangkan oleh Othman et al (2009) dengan menambahkan satu tema pengungkapan yaitu tema tata kelola perusahaan.

Perbankan syariah sebagaimana halnya perbankan konvensional pada umumnya merupakan lembaga intermediasi keuangan (financial intermediary institution) yakni lembaga yang melakukan kegiatan menghimpun dana dari masyarakat dalam bentuk simpanan dan menyalurkannya kepada masyarakat lain yang membutuhkan dalam bentuk kredit atau pembiayaan. Perbankan merupakan lembaga keuangan yang menekankan pada prinsip kepercayaan (fiduciary people), sehingga dalam rangka meningkatkan kepercayaan masyarakat terhadap bank syariah diperlukan adanya pelaksanaan prinsip tata kelola perusahaan yang baik atau yang lebih dikenal dengan prinsip Good Corporate Governance (GCG). Penerapan GCG dapat membantu bank syariah meminimalisasi kualitas pembiayaan yang tidak baik, 
meningkatkan akurasi penilaian bank, infrastruktur, kualitas pengambilan keputusan bisnis dan mempunyai sistem deteksi dini terhadap high risk business area, product and service (Nurhikmah, 2015).

Dukungan terhadap penerapan GCG pada perbankan syariah juga diberikan oleh Bank Indonesia yang tercantum dalam Peraturan Bank Indonesia (PBI) No. 11/33/PBI/2009 tentang Pelaksanaan Good Corporate Governance bagi Bank Umum Syariah dan Unit Usaha Syariah yang kemudian diatur juga dalam Surat Edaran Bank Indonesi No. 12/13/Dpbs perihal pelaksaan GCG pada Bank Umum Syariah dan Unit Usaha Syariah. Peraturan ini melengkapi peraturan pelaksanaan tata kelola perusahaan yang baik bagi perbankan syariah berdasarkan UU No. 21 tahun 2008 tentang Perbankan Syariah.

PBI No. 11/33/PBI/2009 mengatur pelaksanaan GCG yang berlandaskan pada prinsip keterbukaan, akuntabilitas, pertanggungjawaban (responsibility), profesional dan kewajaran. Hal paling mendasar yang membedakan pelaksanaan GCG pada perbankan syariah dan konvensional adalah penerapan prinsip kepatuhan syariah (shariah compliance) yang menjadi pilar utama keberlangsungan entitas bank syariah. Penerapan shariah compliance diwujudkan dengan adanya Dewan Pengawas Syariah (DPS). Peran penting Dewan Pengawas Syariah dalam adalah bertanggung jawab mengawasi layanan, produk yang ditawarkan oleh bank dan operasional bank sudah menerapkan serta mematuhi prinsip- prinsip syariah.

Pengungkapan CSR merupakan salah satu kebijakan manajemen yang dapat dipengaruhi oleh DPS. Pengaruh DPS dalam pengungkapan CSR tersebut didukung oleh teori keagenan, teori stakeholder dan teori legitimasi. Chariri (2012) berpendapat bahwa dalam teori keagenan, DPS hadir untuk mengurangi asimetri informasi atau agency problem. Teori stakeholder adalah teori yang menggambarkan kepada pihak mana saja perusahaan bertanggungjawab (Freeman, 2001). Teori legitimasi terkait dengan pengungkapan CSR menjelaskan bahwa perusahaan beroperasi dalam lingkungan eksternal yang berubah secara konstan dan mereka berusaha meyakinkan bahwa perilaku mereka sesuai dengan batas dan norma masyarakat (Brown dan Deegan, 1998 dalam Michelon dan Parbonetti, 2010).

Dewan Pengawas Syariah yang menjabat pada beberapa bank syariah dapat meningkatkan pengungkapan informasi karena dapat melakukan perbandingan pada beberapa pelaporan perusahaan sehingga dapat mengetahui pelaporan manakah yang terbaik (Hannifa dan Cooke (2000), Abdullah et.al, 2011). Farook et al. (2011) menegaskan bahwa keberadaan DPS di bank syariah dapat meningkatkan pemantauan, dan akan menyebabkan penyediaan informasi lebih lanjut tentang CSR. Hal ini dapat dikatakan bahwa bank syariah yang memiliki DPS yang kuat cenderung mengungkapkan informasi CSR yang lebih dalam laporan tahunan perbankan syariah. (Grais dan Pellegrini 2006; Haniffa dan Cooke, 2005; Nathan dan Pierce, 2009). Berdasarkan uraian tersebut maka dapat dirumuskan hipotesis berikut:

Ha1: Dewan Pengawas Syariah berpengaruh positif terhadap Pengungkapan CSR Bank Syariah di Indonesia.

Ha2: Intellectual Capital berpengaruh positif terhadap Pengungkapan CSR Bank Syariah di Indonesia.

Ha3: Dewan Pengawas Syariah berpengaruh positif terhadap Kinerja Keuangan Bank Syariah di Indonesia.

Ha3: Kinerja Keuangan memediasi hubungan antara Dewan Pengawas Syariah dengan Pengungkapan CSR Bank Syariah di Indonesia. 
Ha4: Intellectual Capital berpengaruh positif terhadap Kinerja Keuangan Bank Syariah di Indonesia.

Ha4: Kinerja Keuangan memediasi hubungan antara Intellectual Capital dengan Pengungkapan CSR Bank Syariah di Indonesia.

Ha5: Kinerja Keuangan berpengaruh positif terhadap Pengungkapan CSR Bank Syariah di Indonesia.

\section{TEORI DAN METODE}

Populasi adalah jumlah keseluruhan objek penelitian. Populasi dalam penelitian ini adalah seluruh bank umum syariah di Indonesia yang berjumlah 11 unit bank sejak tahun 2010 s.d. 2017. Unit analisis yang digunakan adalah annual report bank umum syariah yang dapat diakses dari website masing-masing bank. Penentuan sampel yang digunakan adalah purposive sampling, yaitu hanya data yang memenuhi kriteria yang akan dijadikan sampel.

Teknik analisis data yang digunakan adalah Partial least Square (PLS). Partial Least Square (PLS) merupakan salah satu metode untuk melaksanakan model Structural Equation Modelling (SEM). PLS dapat digunakan dengan jumlah sampel yang tidak besar dan dapat diterapkan pada semua skala data (Latan dan Ghozali, 2012). Analisis SEM dengan efek mediasi digunakan untuk mengetahui pengaruh Dewan Pengawas Syariah dan Komponen Intellectual Capital terhadap pengungkapan CSR dengan kinerja keuangan bank syariah Berikut adalah model persamaan dalam penelitiaan ini dapat digambarkan sebagai berikut:

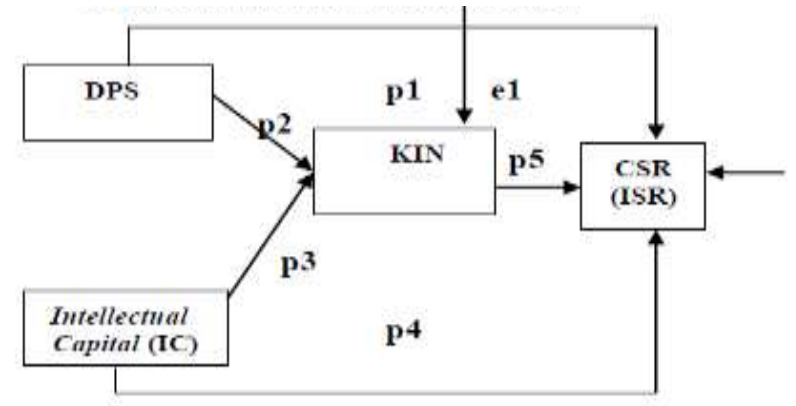

Gambar 1. Model Penelitian

Formulasi matematis dari path analysis (Ghozali, 2011) adalah :

Pengaruh Langsung DPS ke CSR $\quad=\mathrm{p} 1$

Pengaruh tidak langsung DPS ke KIN ke ISR $\quad=\underline{\mathrm{p} 2 \times \mathrm{p} 5}$

Total pengaruh (korelasi DPS ke ISR) $\quad=\mathrm{p} 1+(\mathrm{p} 2 \times \mathrm{p} 5)$

Pengaruh Langsung iB-VAIC ke ISR $\quad=\mathrm{p} 4$

Pengaruh tidak langsung iB-VAIC ke KK ke ISR $=\mathrm{p} 3 \mathrm{xp} 5$

Total pengaruh (korelasi DPS ke ISR) =p3+(p4xp5)

\subsection{Teori}

\subsubsection{Variabel Dependen}

Variabel dependen dalam penelitian ini adalah pengungkapan Corporate Social Responsibility (CSR) dalam perspektif Islam. CSR adalah bentuk aktivitas yang dilakukan perusahaan untuk meningkatkan ekonomi perusahaan sekaligus peningkatan kualitas hidup karyawan dan juga kualitas hidup masyarakat sekitar (Rosiana, et al., 2013). Pengungkapan CSR dalam perspektif Islam menggunakan indeks Islamic Social Reporting (ISR). 
Pokok-pokok pengungkapan sosial yang digunakan dalam penelitian ini merujuk pada penelitian Raditya (2012) yang meliputi enam tema pengungkapan CSR berdasarkan indeks ISR yaitu keuangan dan investasi, produk dan jasa, tenaga kerja, lingkungan dan tata kelola perusahaan. Item pengungkapannya berjumlah 48 item yang tersusun dalam enam tema (Raditya, 2012). Nilai indeks tersebut diperoleh dari content analysis pada laporan tahunan perbankan syariah. Masing-masing item pengungkapan memiliki nilai 1 apabila item pada indeks ISR terdapat dalam data perusahaan, dan nilai 0 diberikan pada sebaliknya. Nilai-nilai tersebut akan dijumlahkan baik menurut masing-masing tema maupun secara keseluruhan. Adapun rumus perhitungan CSR adalah sebagai berikut :

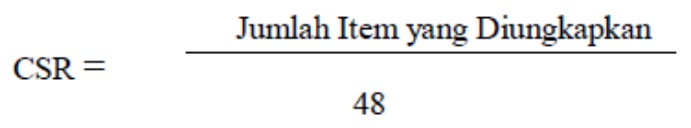

\subsubsection{Variabel Independen}

Variabel independen dalam penelitian ini adalah Intellectual Capital (IC) dan Dewan Pengawas Syariah.

\subsubsection{Intellectual Capital (IC)}

Variabel independen dalam penelitian ini adalah Intellectual Capital. Intellectual capital adalah selisih antara nilai pasar perusahaan dan nilai buku yang merupakan bentuk dari aset tidak berwujud akibat dari materi intelektual (pengetahuan, informasi, properti intelektual, pengalaman) yang dapat menjadikan perusahaan berfungsi, berkompetisi dan unggul.

Berikut tiga rumus yang digunakan dalam iB-VAIC, diantaranya:

$>\quad$ Tahap pertama dengan menghitung iB-Value added (iB-VA). IB-VA dihitung dengan menggunakan cara sebagai berikut:

IB-VA=OUT-IN

OUT (output) : Total pendapatan, diperoleh dari:

IN (input) : Beban usaha/operasional dan beban non operasional kecuali beban kepegawaian

Tahap kedua dengan menghitung Value Added Capital Employee (iB- VACA), adalah indikator untuk iB-VA yang diciptakan oleh satu unit dari human capital. Rasio ini menunjukkan kontibusi yang dibuat oleh setiap unit dari CE (Capital Employed : dana yang tersedia (total ekuitas)terhadap value added perusahaan).

$\mathrm{iB}-\mathrm{VACA}=\mathrm{iB}-\mathrm{VA} / \mathrm{CE}$

Tahap ketiga dengan menghitung Value Added Human Capital (iB- VAHU), menunjukkan berapa banyak iB-VA dapat dihasilkan dengan dana yang dikeluarkan untuk tenaga kerja. iB-VA menunjukkan kontribusi yang dibuat oleh setiap rupiah yang diinvestasikan dalam HC (Human capital : beban karyawan terhadap value added organisasi).

$\mathrm{iB}-\mathrm{VAHU}=\mathrm{iB}-\mathrm{VA} / \mathrm{HC}$

Tahap keempat dengan menghitung Structural Capital Value Added (iB- STVA), mengukur jumlah SC yang dibutuhkan untuk menghasilkan satu rupiah dari iB-VA dan merupakan indikasi bagaimana keberhasilan SC dalam penciptaan nilai. SC adalah Structural capital = IB-VA - HC

$\mathrm{iB}-\mathrm{STVA}=\mathrm{SC} / \mathrm{iB}-\mathrm{VA}$ 
Tahap kelima menghitung iB-VAIC. iB-VAIC mengindikasikan kemampuan intelektual organisasi. iB- VAIC merupakan penjumlahan dari tiga komponen sebelumnya.

$i B-V A I C=i B-V A C A+i B-V A H U+i B-S T V A$

\subsubsection{Dewan Pengawas Syariah}

Dewan Pengawas Syariah (DPS) adalah bagian dari lembaga keuangan syariah yang penempatannya atas persetujuan DSN-MUI (Dewan Syariah Nasional Majelis Ulama Indonesia). Di luar negeri DPS disebut juga sebagai Sharia Supervisoy Board (SSB), atau Sharia Committee, atau Sharia Council, dan sebagainya. DPS turut mempengaruhi kebijakan manajemen, secara khusus termasuk dalam hal pengungkapan CSR (Chariri, 2012).

Pengukuran DPS dalam penelitian ini, dihitung dengan menggunakan skor tingkat pendidikan anggota DPS, jumlah anggota DPS, dan lintas jabatan anggota DPS yang dinilai dengan skala pengukuran sebagai berikut:

a. Tingkat pendidikan anggota DPS: anggota DPS dengan kualifikasi doctoral: 1 , lainnya 0 .

b. Jumlah anggota DPS: 1 untuk bank dengan anggota 3 orang, dan 0 dibawah 3.

c. Lintas jabatan anggota DPS: 1 untuk anggota DPS dengan lintas jabatan, lainnya 0.

\subsubsection{Variabel Mediasi}

\subsubsection{Kinerja Keuangan}

Kinerja keuangan berperan sebagai variabel mediasi dalam hubungan Dewan Pengawas Syariah dan Intellectual Capital terhadap pengungkapan CSR, dan menjadi variabel independen dalam hubungan kinerja keuangan terhadap pengungkapan CSR. Kinerja keuangan merupakan suatu gambaran tentang kondisi keuangan suatu perusahaan yang dianalisis dengan alat-alat analisis keuangan, sehingga dapat diketahui mengenai baik buruknya keadaan suatu perusahaan yang mencerminkan prestasi kerja dalam periode tertentu. Kinerja keuangan dalam penelitian ini diukur menggunakan rasio keuangan bank sesuai dengan Surat Edaran BI No. 9/24/DPbS/2007 yang mencakup aspek- aspek sebagai berikut:

a. Aspek Permodalan. Analisis Permodalan suatu bank lebih dimaksudkan untuk mengetahui bagaimana modal bank tersebut telah memadai untuk menunjang kewajiban jangka panjang. Aspek permodalan diproksikan dengan CAR (Capital Adequacy Ratio).

b. Aspek Kualitas Aset (asset quality). Penilaian kualitas aset suatu bank dimaksudkan untuk mengetahui seberapa besar aset tersebut memiliki risiko. Non Performing Financing (NPF) digunakan untuk mengukur tingkat permasalahan pembiayaan yang dihadapi bank.

c. Aspek Rentabilitas (earnings). Rentabilitas merupakan alat untuk mengukur tingkat efisiensi usaha dan kemampuan bank dalam menghasilkan laba atas asset-aset yang ditanamkan dalam bank tersebut. Rasio rentabilitas yang digunakan adalah ROA dan ROE, yang menunjukkan kemampuan bank untuk memperoleh laba atas sejumlah aset dan ekuitas yang dimiliki.

d. Aspek Manajemen (management). Aspek Manajemen dalam penelitian ini tidak menggunakan pola yang ditetapkan oleh Bank Indonesia, tetapi diproyeksikan dengan pendapatan operasional (operating margin). Rasio yang digunakan yaitu Net Operating Margin (NOM) untuk mengetahui kemampuan aset dalam menghasilkan laba.

e. Aspek Likuiditas (liquidity). Penilaian faktor likuiditas digunakan untuk mengukur kemampuan bank dalam memenuhi kewajiban jangka pendek. Dalam penelitian ini, rasio 
yang digunakan untuk menilai faktor likuiditas adalah Rasio Financing to Deposits Ratio (FDR).

\subsection{Gambar}

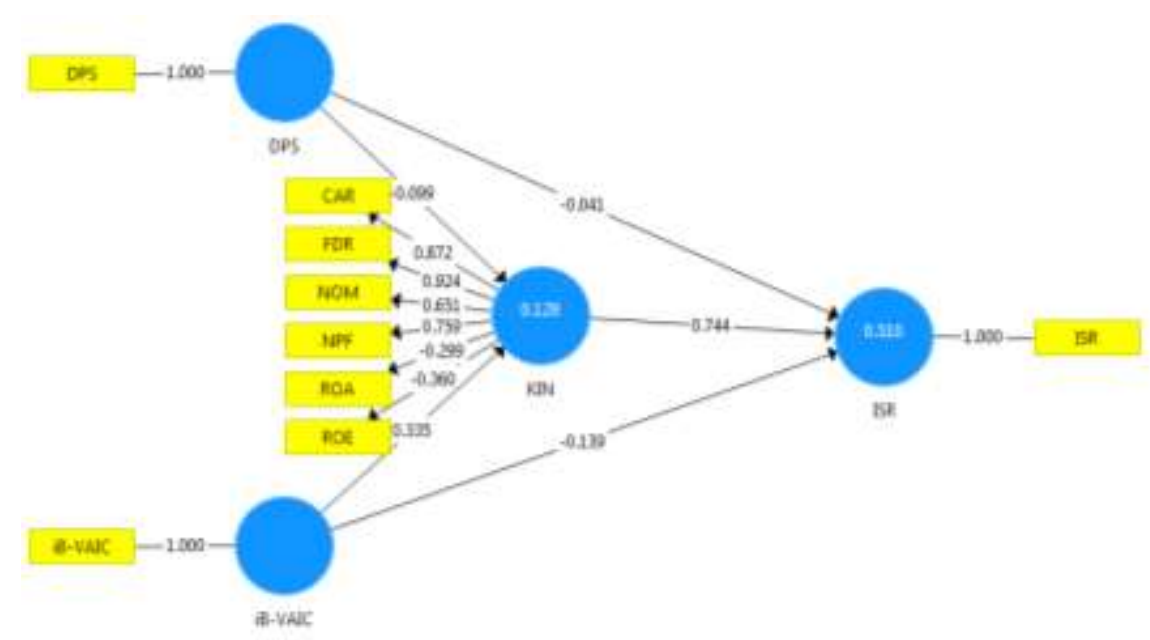

\section{Gambar 2. Hasil Penelitian-Nilai Outer Weights}

(Data sekunder diolah dengan SmartPLS 3.0, 2018)

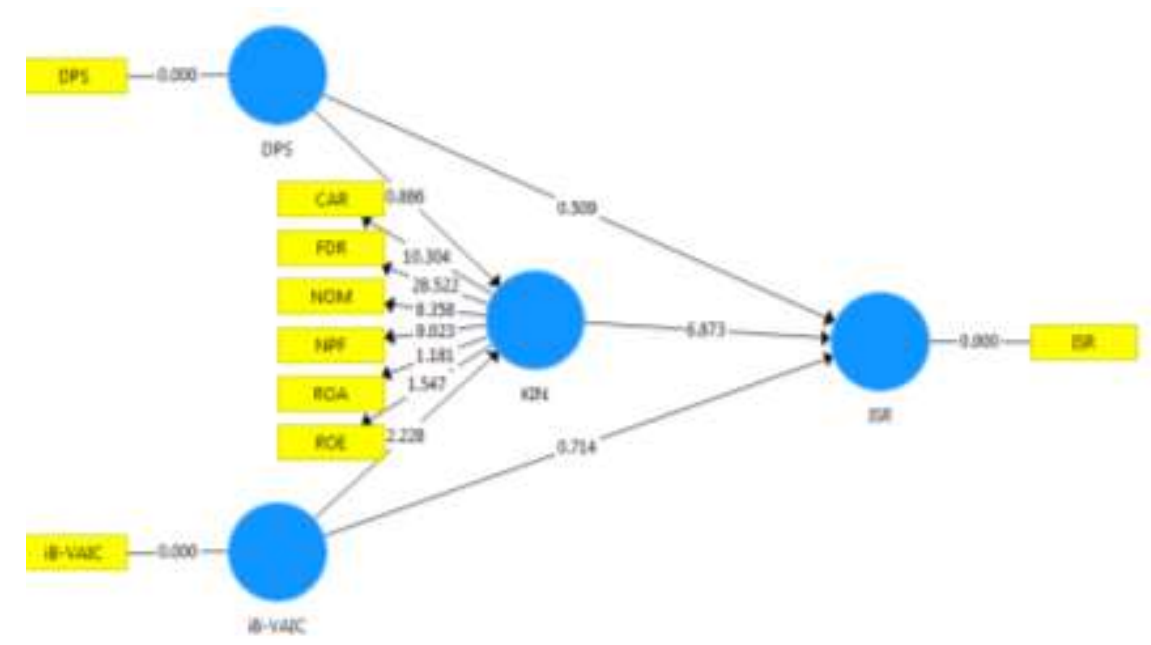

Gambar 3. Hasil Penelitian-Nilai Inner Weights

(Data sekunder diolah dengan SmartPLS 3.0, 2018)

\subsection{Tabel}

Tabel 1. Nilai Outer Weights

\begin{tabular}{|c|c|c|c|c|c|}
\hline & $\begin{array}{c}\text { Original } \\
\text { Sample (O) }\end{array}$ & $\begin{array}{c}\text { Sample Mean } \\
(M)\end{array}$ & $\begin{array}{c}\text { Standard Error } \\
\text { (STERR) }\end{array}$ & $\begin{array}{c}\text { T Statistics } \\
\text { (|O/STERR/) }\end{array}$ & P Values \\
\hline CAR <- KIN & 0,340 & 0,325 & 0,031 & 8,998 & 0,000 \\
\hline DPS <- DPS & 1,000 & 1,000 & 0,000 & & 0,000 \\
\hline FDR <- KIN & 0,369 & 0,353 & 0,025 & 14,269 & 0,000 \\
\hline ISR <- ISR & 1,000 & 1,000 & 0,000 & & 5,304 \\
\hline NOM <- KIN & 0,193 & 0,189 & 0,022 & & 0 \\
\hline
\end{tabular}




\begin{tabular}{|c|c|c|c|c|c|}
\hline NPF <- KIN & 0,245 & 0,254 & 0,029 & 7,234 & 0,000 \\
\hline ROA <- KIN & $-0,070$ & $-0,056$ & 0,071 & 0,890 & 0,374 \\
\hline ROE <- KIN & $-0,082$ & $-0,068$ & 0,060 & 1,179 & 0,239 \\
\hline iBVAIC <- VAIC & 1,000 & 1,000 & 0,000 & & \\
\hline
\end{tabular}

Tabel 2. Nilai R-Square

\begin{tabular}{|c|c|c|}
\hline & R Square & $\begin{array}{c}\text { R Square } \\
\text { Adjusted }\end{array}$ \\
\hline ISR & 0,510 & 0,491 \\
\hline KIN & 0,129 & 0,107 \\
\hline
\end{tabular}

Tabel 3. Nilai Inner Weights

\begin{tabular}{|c|c|c|c|c|c|c|}
\hline & $\begin{array}{c}\text { Original } \\
\text { Sample (O) }\end{array}$ & $\begin{array}{c}\text { Sample } \\
\text { Mean (M) }\end{array}$ & $\begin{array}{c}\text { T-Statistics } \\
(T S)\end{array}$ & $\begin{array}{c}\text { T-tabel } \\
(T t)\end{array}$ & Hasil & Keterangan \\
\hline DPS -> ISR & $-0,041$ & $-0,043$ & 0,509 & 1,96 & Ts $<\mathrm{Tt}$ & Tidak Signifikan \\
\hline DPS -> KIN & $-0,099$ & $-0,089$ & 0,886 & 1,96 & Ts $<\mathrm{Tt}$ & Tidak Signifikan \\
\hline iB-VAIC -> ISR & $-0,139$ & $-0,057$ & 0,714 & 1,96 & Ts $>$ Tt & Tidak Signifikan \\
\hline iB-VAIC -> KIN & 0,335 & 0,422 & 2,228 & 1,96 & Ts $>$ Tt & Positif Siginifikan \\
\hline KIN -> ISR & 0,744 & 0,703 & 6,873 & 1,96 & Ts $>$ Tt & Positif Siginifikan \\
\hline
\end{tabular}

Sumber: Data sekunder diolah dengan SmartPLS 3.0, 2018

Tabel 4. Hasil Pengujian Pengaruh Langsung

\begin{tabular}{|c|c|c|c|c|c|c|c|}
\hline $\begin{array}{c}\text { Variabel } \\
\text { Independen }\end{array}$ & $\begin{array}{c}\text { Variabel } \\
\text { Dependen }\end{array}$ & Hipotesis & Arah & $\begin{array}{c}\text { Besar } \\
\text { Pengaruh }\end{array}$ & $\begin{array}{c}\text { T- } \\
\text { statistik }\end{array}$ & $\begin{array}{c}\text { T- } \\
\text { tabel }\end{array}$ & Keterangan \\
\hline DPS & ISR & H1 & + & $-0,041$ & 0,509 & 1,96 & Tidak Signifikan \\
\hline iB-VAIC & ISR & H2 & + & $-0,099$ & 0,886 & 1,96 & Tidak Signifikan \\
\hline DPS & KIN & H3 & + & $-0,139$ & 0,714 & 1,96 & Tidak Signifikan \\
\hline iB-VAIC & KIN & H4 & + & 0,335 & 2,228 & 1,96 & Signifikan \\
\hline KIN & ISR & H5 & + & 0,744 & 6,873 & 1,96 & Signifikan \\
\hline
\end{tabular}

Sumber: Data sekunder diolah, hasil output smartpls 3.02018

Tabel 5. Hasil Pengujian Tidak Langsung (indirect effect)

\begin{tabular}{|c|c|c|c|c|}
\hline Pengaruh & Besar Pengaruh & T-statistik & T-tabel & Keterangan \\
\hline DPS-KIN-ISR & $-0,074$ & 0,195 & 1,96 & Tidak Signifikan \\
\hline iBVAIC -KIN-ISR & 0,249 & 2,734 & 1,96 & Signifikan \\
\hline
\end{tabular}

Sumber: Data sekunder diolah, hasil output smartpls 3.02018

Tabel 6. Pengaruh Total Hubungan antara DPS dan Pengungkapan ISR dengan Kinerja Keuangan sebagai Variabel Mediasi

\begin{tabular}{|c|c|c|c|c|}
\hline Pengaruh & Besar Pengaruh & T-statistik & T-tabel & Keterangan \\
\hline DPS-ISR & $-0,041$ & 0,509 & 1,96 & Tidak Signifikan \\
\hline DPS-KIN & $-0,099$ & 0,886 & 1,96 & Tidak Signifikan \\
\hline KIN-ISR & 0,744 & 6,873 & 1,96 & Signifikan \\
\hline DPS-KIN-ISR & $-0,074$ & 0,915 & 1,96 & Tidak Signifikan \\
\hline
\end{tabular}

Sumber: Data sekunder diolah, hasil output smartpls 3.02018 
Tabel 7. Pengaruh Total Hubungan antara iB-VAIC dan Pengungkapan ISR dengan Kinerja Keuangan sebagai Variabel Mediasi

\begin{tabular}{|c|c|c|c|c|}
\hline Pengaruh & Besar Pengaruh & T-statistik & T-tabel & Keterangan \\
\hline iBVAIC-ISR & $-0,139$ & 0,469 & 1,96 & Tidak Signifikan \\
\hline iBVAIC-KIN & 0,335 & 2,228 & 1,96 & Signifikan \\
\hline KIN-ISR & 0,744 & 6,873 & 1,96 & Signifikan \\
\hline iBVAIC -KIN-ISR & 0,249 & 2,734 & 1,96 & Signifikan \\
\hline
\end{tabular}

Sumber: Data sekunder diolah, hasil output smartpls 3.02018

\section{PEMBAHASAN}

\subsection{Pengaruh Dewan Pengawas Syariah (DPS) terhadap Pengungkapan CSR.}

Hasil pengujian hipotesis pertama menunjukan bahwa pengaruh variabel DPS terhadap Pengungkapan CSR yang diproksikan dengan indeks ISR menunjukkan nilai Tstatistik sebesar 0,509. Nilai tersebut lebih kecil dari T-tabel $(1,96)$. Hasil ini berarti bahwa DPS tidak berpengaruh terhadap pengungkapan CSR (ISR). Hal ini berarti bahwa hipotesis 1 yang menyebutkan DPS berpengaruh positif terhadap pengungkapan CSR tidak diterima.

Hal ini tidak sesuai dengan teori yang mendukung penelitian ini yaitu teori stakeholder dan teori keagenan. Hasil peneltian ini tidak sejalan dengan pendapat Abdullah et al. (2011). Namun, hasil penelitian ini sesuai dengan yang dilakukan oleh Rizkiningsih (2012) dan Dipika (2014) yang menyatakan bahwa DPS tidak berpengaruh terhadap pengungkapan CSR pada bank syariah.

\subsection{Pengaruh Intellectual Capital (iB- VAIC) terhadap Pengungkapan CSR.}

Hasil pengujian hipotesis kedua menunjukan bahwa pengaruh variabel IC terhadap Pengungkapan CSR yang diproksikan dengan indeks ISR menunjukkan nilai T- statistik sebesar 0,886. Nilai tersebut lebih kecil dari T-tabel $(1,96)$. Hasil ini berarti bahwa IC berpengaruh positif tetapi tidak cukup signifikan terhadap pengungkapan CSR (ISR). Hal ini berarti bahwa hipotesis 2 yang menyebutkan IC berpengaruh positif terhadap pengungkapan CSR tidak diterima.

Hal ini tidak sesuai dengan teori yang mendukung penelitian ini yaitu resourced based theory (RBT), knowledge based theory (KBV) dan teori legitimasi. Hasil penelitian ini sesuai dengan hasil penelitian yang dilakukan oleh Musibah dan Wan (2014) yang menyatakan bahwa IC tidak berpengaruh terhadap pengungkapan CSR bank syariah.

\subsection{Pengaruh Dewan Pengawas Syariah (DPS) terhadap Kinerja Keuangan Bank Syariah di Indonesia.}

Hasil pengujian hipotesis ketiga menunjukan bahwa pengaruh variabel DPS terhadap Kinerja Keuangan Bank Syariah di Indonesia yang diproksikan dengan CAR, NPF, ROA, ROE, NOM dan FDR menunjukkan nilai T-statistik sebesar 0,714. Nilai tersebut lebih kecil dari Ttabel $(1,96)$. Hasil ini berarti bahwa DPS tidak berpengaruh signifikan terhadap kinerja keuangan bank syariah di Indonesia. Hal ini berarti bahwa hipotesis 3 tidak dapat diterima. Hasil ini tidak sesuai dengan penelitian yang dilakukan oleh Musibah dan Wan (2014) yang menyatakan bahwa DPS berpengaruh terhadap kinerja keuangan bank syariah. 


\subsection{Pengaruh Intellectual Capital (iB- VAIC) terhadap Kinerja Keuangan Bank Syariah di Indonesia.}

Hasil pengujian hipotesis keempat menunjukan bahwa pengaruh variabel IC terhadap Kinerja Keuangan Bank Syariah di Indonesia yang diproksikan dengan CAR, NPF, ROA, ROE, NOM dan FDR menunjukkan nilai T-statistik sebesar 2,228. Nilai tersebut lebih kecil dari Ttabel $(1,96)$. Hasil ini berarti bahwa IC berpengaruh positif dan signifikan terhadap kinerja keuangan bank syariah di Indonesia. Hal ini berarti bahwa hipotesis 4 yang menyebutkan IC berpengaruh positif terhadap kinerja keuangan bank syariah diterima.

Hasil uji hipotesis menunjukkan bahwa IC berpengaruh positif dan signifikan terhadap kinerja keuangan bank syariah di Indonesia yang dibentuk dari perhitungan komponen IC yaitu capital employed, human capital, structural capital. Hal ini sesuai dengan teori yang mendukung penelitian hubungan Intellectual Capital (IC) dengan kinerja keuangan yaitu resourced based theory (RBT), knowledge based theory, dan stakeholder theory. Hasil ini sesuai dengan penelitian yang dilakukan oleh Musibah dan Wan (2014), dan Ulum, dkk (2008) yang menyatakan bahwa IC berpengaruh positif terhadap kinerja keuangan bank syariah.

\subsection{Pengaruh Kinerja Keuangan Bank Syariah terhadap Pengungkapan CSR Bank Syariah di Indonesia.}

Hasil pengujian hipotesis kelima menunjukan bahwa pengaruh variabel mediasi kinerja keuangan bank syariah di Indonesia terhadap pengungkapan CSR menunjukan nilai Tstatistik sebesar 6,873. Nilai tersebut lebih besar dari T-tabel $(1,96)$. Hasil ini berarti bahwa kinerja keuangan bank syariah berpengaruh positif dan signifikan terhadap pengungkapan CSR (ISR). Hal ini berarti bahwa hipotesis 5 yang menyebutkan kinerja keuangan bank syariah berpengaruh positif terhadap pengungkapan CSR diterima.

Hasil uji hipotesis menunjukkan bahwa kinerja keuangan bank syariah di Indonesia yang dibentuk dari proksi CAR, NPF, ROA, ROE, NOM dan FDR berpengaruh positif dan signifikan terhadap pengungkapan CSR. Kinerja keuangan bank syariah yang di bentuk dari enam (6) proksi yaitu CAR, NPF, ROA, ROE, NOM dan FDR menunjukkan bahwa kemampuan ROA dan ROE menjadi indikator yang tidak valid untuk variabel kinerja keuangan. CAR, NOM, NPF, FDR menjadi indikator yang valid untuk mengukur kinerja keuangan bank syariah. Hal ini sesuai dengan hasil penelitian sebelumnya yang dilakukan oleh Hannifa dan Cooke (2005), Othman et.al (2009), Ayu (2010), Rizkiningsih (2012) dan Widiasti (2013).

\subsection{Pengaruh Kinerja Keuangan sebagai Variabel Mediasi}

\subsection{Kinerja Keuangan memediasi hubungan antara Dewan Pengawas Syariah dengan Pengungkapan CSR Bank Syariah di Indonesia}

Hasil pengujian pengaruh tidak langsung DPS terhadap pengungkapan CSR menunjukan bahwa pengaruh variabel DPS terhadap pengungkapan CSR yang di mediasi oleh variabel Kinerja Keuangan Bank Syariah di Indonesia yang diproksikan dengan CAR, NPF, ROA, ROE, NOM dan FDR menunjukkan nilai T-statistik sebesar 0,509. Pengaruh tidak langsung ini hasilnya tidak signifikan dimana nilai T-statistik $(0,509)$ lebih kecil dari T-tabel $(1,96)$. Sedangkan, berdasarkan tabel 6 hasil pengujian hipotesis pengaruh total untuk variabel DPS memberikan pengaruh total terhadap pengungkapan CSR mencapai 0,915 dan bernilai positif dan lebih besar dibandingkan pengaruh langsung DPS dengan pengungkapan 
CSR yang hanya mencapai 0,509 . Hasil uji statistik juga menunjukkan bahwa nilai T- statistik sebesar 0,915 lebih kecil dibandingkan dengan nilai T-tabel $(1,96)$, sehingga pengaruh ini dapat dinyatakan tidak signifikan. Hal ini menunjukkan bahwa hipotesis yang menyebutkan Kinerja Keuangan memediasi hubungan antara Dewan Pengawas Syariah dengan Pengungkapan CSR Bank Syariah di Indonesia tidak diterima. Hal ini tidak sesuai dengan teori yang mendukung penelitian ini yaitu teori keagenan, teori stakeholder dan teori sumber daya ketergantungan. Hasil ini tidak sesuai dengan penelitian yang dilakukan oleh Musibah dan Wan (2014) yang menyatakan bahwa Kinerja Keuangan memediasi hubungan antara Dewan Pengawas Syariah dengan Pengungkapan CSR Bank Syariah di Indonesia.

\subsection{Kinerja Keuangan memediasi hubungan antara Intellectual Capital dengan Pengungkapan CSR Bank Syariah di Indonesia}

Hasil pengujian pengaruh tidak langsung IC terhadap pengungkapan CSR menunjukan bahwa pengaruh variabel IC terhadap pengungkapan CSR yang di mediasi oleh variabel Kinerja Keuangan Bank Syariah di Indonesia yang diproksikan dengan CAR, NPF, ROA, ROE, NOM dan FDR menunjukkan nilai T-statistik sebesar 2,734. Nilai tersebut lebih besar dari Ttabel $(1,96)$ sehingga adanya variabel kinerja keuangan sebagai variabel mediasi mampu meningkatkan hubungan IC dengan pengungkapan CSR. Hasil ini berarti bahwa variabel IC yang di mediasi oleh kinerja keuangan berpengaruh positif terhadap pengungkapan CSR dengan pengaruh yang signifikan dimana T-statistik $(2,734)$ lebih besar daripada T-tabel $(1,96)$. Selain itu, berdasarkan tabel 7 hasil pengujian hipotesis pengaruh total untuk variabel IC memberikan pengaruh total terhadap pengungkapan CSR mencapai 2,228 dan bernilai positif. Berdasarkan uji statistik menunjukkan bahwa nilai T- statistik sebesar 2,228 lebih besar dibandingkan dengan nilai T-tabel $(1,96)$, sehingga pengaruh ini dapat dinyatakan signifikan. Hal ini berarti bahwa hipotesis yang menyebutkan Kinerja Keuangan memediasi hubungan antara Intellectual Capital dengan Pengungkapan CSR Bank Syariah di Indonesia diterima.

Hal ini sesuai dengan teori yang mendukung penelitian ini yaitu teori berbasis sumber daya (RBT). Hasil ini sesuai dengan penelitian yang dilakukan oleh Musibah dan Wan (2014) yang menyatakan bahwa Kinerja Keuangan memediasi hubungan antara Intellectual Capital dengan Pengungkapan CSR Bank Syariah di Indonesia.

\section{PENUTUP}

Berdasarkan hasil penelitian dari analisis data pada bab 4 mengenai pengaruh Dewan Pengawas Syariah (DPS) dan Intellectual Capital (IC) terhadap pengungkapan CSR dengan Kinerja Keuangan Bank Syariah di Indonesia sebagai variabel mediasi, maka dapat dibuat kesimpulan sebagai berikut:

1. Dewan Pengawas Syariah (DPS) tidak berpengaruh positif terhadap pengungkapan CSR bank syariah di Indonesia.

2. Intellectual Capital (IC) tidak berpengaruh positif terhadap pengungkapan CSR bank syariah di Indonesia.

3. Dewan Pengawas Syariah (DPS) berpengaruh positif terhadap kinerja keuangan bank syariah di Indonesia, namun tidak signifikan sehingga tidak dapat diterima.

4. Intellectual Capital (IC) berpengaruh positif terhadap kinerja keuangan bank syariah di Indonesia. 
5. Kinerja keuangan bank syariah di Indonesia bepengaruh positif terhadap pengungkapan CSR.

6. Kinerja keuangan yang dibentuk dari proksi CAR, NPF, ROA, ROE, NOM dan FDR tidak mampu memediasi hubungan antara DPS dengan Pengungkapan CSR bank syariah di Indonesia.

7. Kinerja keuangan yang dibentuk dari proksi CAR, NPF, ROA, ROE, NOM dan FDR mampu memediasi hubungan IC terhadap Pengungkapan CSR bank syariah di Indonesia. 


\section{REFERENSI}

Agustina, Wahyuni, dkk. 2015. "Pengaruh Intellectual Capital, Corporate Social Responsibility Dan Good Corporate Governance Terhadap Kinerja Keuangan (Studi Kasus pada Perusahaan BUMN yang Terdaftar di BEI tahun 2011-2013)", (Uurnal Akuntansi, Universitas Pendidikan Ganesha) Vol. 3 No. 1 Tahun 2015

Arani, Desna. 2010. "Hubungan Penerapan Prinsip Good Corporate Governance Terhadap Kinerja Keuangan PT. Bank Syariah Mandiri”, (Skripsi Fakultas Ekonomi, Universitas Gunadarma), Jakarta.- Dipublikasikan

Charles, Chariri. 2012. "Analisis Pengaruh Corporate Governance terhadap Pengungkapan Corporate Social Responsibility (Studi Kasus pada Bank Syariah di Asia)". (Diponegoro Journal of Accounting) -Tahun 2012.

Dipika, Nur Anisa. 2014. "Pengaruh Good Corporate Governance, Ukuran Perusahaan, dan Profitabilitas terhadap Pengungkapan Islamic Social Reporting (Studi Kasus pada Perbankan Syariah Di Indonesia)", (Skripsi Fakultas Syariah dan Hukum, Universitas Islam Negeri Sunan Kalijaga), Yogyakarta.-Dipublikasikan

Ekayani, Fitria dan Anton Rahmadi. 2010. "Rangkuman Prinsip Syariah dalam Tata Kelola Perusahaan yang Baik", Artikel Fakultas Ekonomi Universitas Mulawarman, Samarinda.

Fitria, Soraya dan Dwi Hartanti. 2010. “ Islam dan Tanggung Jawab Sosial : Studi

Perbandingan Pengungkapan Berdasarkan Global Reporting Initiative Indeks dan Islamic Social Reporting Indeks" (Jurnal SNA XIII).

Ghozali, Imam dan Hengky Latan. 2012. Partial Least Square Konsep, Teknik dan Aplikasi Menggunakan Program SmartPLS2.0 M3. Badan Penerbit UNDIP: Semarang.

Khoirudin, Amirul. 2013. "Corporate Governance dan Pengungkapan Islamic Social Reporting pada Perbankan Syariah di Indonesia." (Acounting Analysis Journal UNNES) ISSN 2252-6765 Acoounting analysis Journal 2(2)(2013)

Lestari, Puji. 2013. "Determinants Of Islamic Social Reporting In Syariah Banks: Case of Indonesia." (International Journal Business and Management Invention) Vol. 2 No. 10- Oktober 2013.

Maulida, Aldehita Purnasanti dkk. 2012. “Analisis Faktor-Faktor yang Mempengaruhi Pengungkapan Islamic Social Reporting (ISR)", Artikel Fakultas Ekonomi, Universitas Negeri Semarang. 
Musibah, Anwar Salem dan Wan Sulaiman Bin Wan Yusoff Alfattani. 2014. "The Mediating Effect of Financial Performance on the Relationship between Shariah Supervisory Board Effectiveness, Intellectual Capital and Corporate Social Responsibility, of Islamic Banks in Gulf Cooperation Council Countries" (Asian Social Sciences) Vol.10 No. 17 - Tahun 2013).

Othman, Rohana dan Azlan Md Thani. 2010. "Islamic Social Reporting Of Listed Companies In Malaysia," (International Business \& Economics Research Journal) Vol. 9 No. 4 - April 2010).

Peraturan Bank Indonesia No. 11/33/PBI/2009 tentang Pelaksanaan GCG bagi Bank Umum Syariah dan Unit Usaha Syariah

Putri, Dewi Rosarina R. 2014. " Hubungan Antara Corporate Social Responsibility Dan Kinerja Keuangan Industri Keuangan Syariah Di Indonesia", (Skripsi Fakultas Syariah dan Hukum, Universitas Islam Negeri Sunan Kalijaga), Yogyakarta.- Dipublikasikan

Raditya, Amilia Nurul. 2012. “ Analisis Faktor-Faktor Yang Mempengaruhi Tingkat Pengungkapan Islamic Social Reporting (ISR) Pada Perusahaan Yang Masuk Daftar Efek Syariah (DES)", (Skripsi Fakultas Ekonomi Universitas Indonesia), Depok.- Dipublikasikan

Rahman, Azhar Abdul dan Abdullah Awadh Bukair. 2013. "The Influence of the Shariah Supervision Board on Corporate Social Responsibility Disclosure by Islamic Bank of Gulf Co-Operation Council Countries"(Asian Journal of Business and Accounting) Vol. 6 No. 2- Tahun 2013 (ISSN 1985-4064).

Rahma, Nadia. 2012. “Analisis Penerapan Islamic Social Reporting Index Dalam Pengungkapan Corporate Social Responsibility Perbankan Syariah Indonesia", (Skripsi Fakultas Syariah dan Hukum, Universitas Islam Negeri Sunan Kalijaga), Yogyakarta.- Dipublikasikan

Rizkiningsih, Priyesta. 2012. "Faktor-Faktor yang Mempengaruhi Pengungkapan Islamic Social Reporting (ISR): Studi Empiris pada Bank Syariah di Indonesia, Malaysia, dan Negara- Negara Gulf Cooperation Council”, (Skripsi Fakultas Ekonomi, Universitas Indonesia), Depok.- Dipublikasikan

Sofyani, Hafiez dkk. 2012. "Islamic Social Reporting Index sebagai Model Pengukuran Kinerja Sosial Perbankan Syariah (Studi Komparasi Indonesia dan Malaysia)." (Jurnal Dinamika Akuntansi) Vol. 4 No. 1-Maret 2012: $36-46$ 
Ulum, Ihyaul. 2013. "iB-VAIC: Model Pengukuran Kinerja Intellectual Capital Perbankan Syariah di Indonesia"(Jurnal Inferensi) Vol. 7 No. 1, hlm 183204. ISSN:1978-7332

UU No. 21 tahun 2008 tentang perbankan syariah

Wardayanti, Siti Maria. 2011. “ Implikasi Shariah Governance Terhadap Reputasi dan Kepercayaan Bank Syariah" (Jurnal Walisongo, Universitas Jember) Vol. 19, No. 1 Mei 2011

Widiasti, Asih. 2013. "Faktor-Faktor Yang Mempengaruhi PengungkapanIslamic Social Reporting (ISR) Perusahaan Terdaftar Pada Daftar Efek Syariah (DES)", (Skripsi STIE Bank BPD Jateng), Semarang.- Dipublikasikan

Widyastuti, Sri. 2010. "Dampak Penerapan Tata Kelola Perusahaan Yang Baik Terhadap Kinerja Bank Umum Syariah”, (Skripsi Universitas Pancasila), Jakarta.- Dipublikasikan 